\title{
THE INTERDISCIPLINARY CULTURAL STUdies Paradigm IN THE INDIAN OCEAN
}

\section{Transforming Cultures eJournal, \\ Vol. 3 No 2, November 2008 \\ http://epress.lib.uts.edu.au/journals/TfC}

\section{Stephen Muecke}

In recent years a number of conferences have promoted the idea of an interdisciplinary cultural studies approach to Indian Ocean studies. There was "Eyes Across the Water: Navigating the Indian Ocean", at the University of the Witwatersrand, Johannesburg, $20^{\text {th }}-23^{\text {rd }}$ August 2007. Just before that, Kuala Lumpur saw “The Indian Ocean World", Department of English, University of Malaysia, on $12^{\text {th }}$ August. The previous year we hosted what may have been the first conference of this type at the University of Leiden in the Netherlands: "Culture and Commerce in the Indian Ocean", $25^{\text {th }}-27^{\text {th }}$ September 2006, and this collection of papers emerges from that event. What was at stake was a challenge to area studies of a certain type, and a response to the reemergence of the economic strength of East and South Asia. So, in typical cultural studies fashion, the approach was, and continues to be, one of addressing the "current conjuncture" in the process of reassessing academic approaches.

Postcolonial thought was never very far from our thinking as we developed this interdisciplinary paradigm, and it is that kind of thought (where Ghosh's In an Antique Land (1992), Gilroy's Black Atlantic (1993) and Chakrabarty's Provincializing Europe (2000) are key recent texts that makes an older version of Area Studies (where the carve-up of the Third World happens in the Metropole) impossible to think today. At the same time conjunctural thinking demands we read history and culture with an eye to the present, a present where trade winds of economics and politics are blowing strongly from China and India, such that the era of colonial domination of the Indian Ocean seems well and truly over.

So while the cultural studies approach is not 'disinterested', and remains historically 
contingent and nervously responsive to the present, it is not for all that totally lacking in system. The form that this system might take is not one that is imported as a knowledgegrid from the northern hemisphere, producing colonially useful knowledge for export. It takes its cues from the 'lie of the land' (or rather the sea), the patterns of trade as determined by nature and geography, the weight and mass of populations, natural common wealth and manufactured wealth. And then, in a more superstructural and contemporary sense, forms of culture grow and are fostered by technologies and trade, from the steamship to TV and communications satellites. In this way cultural studies opens up domains that the older disciplines - anthropology, history, international social studies, geography_did not 'see'. Yet the new paradigm is dependent on them, they are the columns to which it adds its over-arching roof. For it cannot supplant them, they are synchronous and a constant source of material, they are linked by the 'roof', and sometimes dialogue with each other, as when the concept of cosmopolitanism is taken out of Europe and re-located in the Indian Ocean, as Akhil Gupta does in this collection. Far from being a product of, or even post-dating, the (modern) formation of nations, he argues that cosmopolitanism was an earlier phenomenon in the inter-civilisational movements of the medieval Indian Ocean and that 'the very vernacularization that is taken as the ground on which national orders and nationalist sentiment are built was itself constructed out of a reaction to cosmopolitan forms that had prevailed earlier'. Gupta thus builds on the arguments that in the Indian Ocean context 'globalization was the normal state', but here he usefully adds the concept of cosmopolitanism without, he convincingly argues, any anachrony.

My own article seeks to exemplify somewhat the approach outlined here, asking what cultural studies can make visible in the Indian Ocean if we ask questions related to the following five topics: cultures of contemporary art, cultures of sport (and the Jeux des Îles de l'Océan Indien), Bollywood in the Indian Ocean, cultures of Australian politics and security, and the changing attitudes towards the trade in ivory. In each case, a particular narrative locates the matter of concern within its historical contingencies, thus exemplifying a cultural studies method which does not package the 'case study' as exportable knowledge.

Gwynn Campbell, tacking in a different direction, towards Africa, also takes an inclusionist line. He criticises area studies 'centrisms' (Eurocentrism, Asiacentism) in 
order to posit a more Braudelian Indian Ocean World where Africa's role can be reassessed as more agentive and less dependent. He urges that inter-regional linkages be more fully recognised and extrapolated, notably in the exchange of peoples, ideas, technology and commodities' because Africa was a key continent in this regard, and in fact, 'Africans [themselves] were responsible for major economic and political developments on the African continent that have traditionally been ascribed to external forces'.

In a close historical and theoretical analysis, G. Balachandran is revealing about the collective action taken by Indian seamen from the late C $19^{\text {th }}$ to the end of WW2. Far from being characterised as the sometimes stereotyped violent rebellion of peasants, this collective action was clearly rational, attuned to the varying global labour market as the world went through depression and war, and adopting its own political style. Balachandran has thus made a significant contribution to (Indian Ocean) labour history in ways that open many further avenues for study.

Still with 'collective strategies', but now stepping into smaller boats with Maarten Bavinck's analysis of fishing and its organisation along the Coromandel coast of Tamil Nadu in the wake of the 2004 tsunami, we find a fascinating confirmation that vernacular social organisation is as rational as it is effectively contingent, and his paper thus demonstrates a significant contribution towards a 'rethinking of community, or caste, organizations in India' where these somewhat precarious uur panchayats can still be effective across a range of activities, as opposed to being 'unwanted expressions of a traditional order', as a more Nehruvian vision of a modern India might have it.

In tune with the vernacular and local emphasis of earlier papers, and with a cultural studies' search for alternative archival sources, Gijsbert Oonk concentrates on 'negotiating Hinduism from below' as he investigates Hindus in East Africa between 1880-1960. His empirical historical approach, using some ethnographic enquiry into food and drink practices, and intermarriage, furthers considerably the understanding of processes of cultural adaptation among Hindus in East Africa.

Rila Mukherjee's examination of the ritual of Bera bhashan, the launching of paper boats into the sea in the Bay of Bengal, is both historical and anthropological. The 
function of the ritual is to tie together the sea and the land, as bounties are sought from both realms and gods are propitiated in this ritual in the liminal space of the sea-shore, where an Islamic culture encounters its diasporic destiny.

Himanshu Ray, on the other hand, is interested in sites, on the relations between 'material culture and texts...between archaeology and history', as she investigates Buddhist temples in colonial and post-colonial India and the role they have played in the restoration or reconstruction of a South Asian and South-East Asian set of histories, before and beyond both colonialism and nationalism. The pressures of politics are thus imbricated with the cultural, for the permanence of sites and the rituals of pilgrimage (not to mention the rituals of knowledge-making) are keys to the formation of historical senses of identity.

We finish with the present, or indeed the twist in time that is implied by the building of a 'postcolonial museum of the present'. The Maison des civilizations et de l'unité Réunionaise (a beautiful shell-like structure rivalling New Caledonia's Tjibaou) will open in 2010. Like the island itself, it is conceived by Françoise Vergès and Carpanin Marimoutou as 'a contact-zone ... in a zone of contacts and conflicts between different worlds'. Fascinatingly, it will be a museum without a collection. It will be 'a "transformative" space where people recognise themselves, their creations and practices', and encounter the heritage and performances of the French, Malagasy, Chinese, and descendents of slaves and indentured labourers from around the Indian Ocean that make up the population of the island. In confronting Reunion's colonial history, the museum, as an intellectual project presented here, will contribute to 'rethinking museums as "sites of frictions" and spaces of exchange'.

That is precisely the kind of keynote our collection strives to sound as it contributes to the postcolonial thought that would take the Indian Ocean out of disciplinary and area studies segmentations. Its unity was never a given, to be claimed by any one approach, (and cultural studies has no greater claim), nor would 'oneness' be a particularly edifying concept if the context is the following: the conjunctions and disjunctions implied by the ocean itself; the oceanic littoral and the islands; the natural logic of the monsoon rhythm creating trade; the movement of people; their anchoring by sacred sites and slowly changing cultural customs; the friction between globalising modernism 
and the inventiveness of vernacular technologies and cultural strategies. In that necessarily complex reality, our methodologies are themselves inventive by contingency and necessity. It is the complex materiality of this Indian Ocean world that speaks to humble researchers, like those we are proud to have brought together here, and challenges them to keep inventing. 